\title{
Bryocoris gracilis (Hemiptera: Miridae) New to Korea
}

\author{
Young Jae Cho ${ }^{1}$, Yong Jung Kwon ${ }^{2, *}$ and Sang Jae Suh ${ }^{3}$ \\ ${ }^{1}$ Gwangyang Branch Office, Homan Regional Office, National Plant Quarantine Service, Gwangyang, Korea \\ ${ }^{2}$ School of Applied Bioscience, Kyungpook National University, Daegu, Korea \\ ${ }^{3}$ School of Applied Ecological Resources, Kyungpook National University, Sangju, Korea
}

\begin{abstract}
Korean Bryocoris species, B. gracilis and B. montanus, were reviewed. Of these, B. gracilis Linnavuori, 1962 is first reported in Korea and diagnosed, based on a single female specimen collected from Mount Hwangmaesan, Gyeongsangnam-do province. A key to the Korean species and photographs on external features are given.
\end{abstract}

Keywords: Hemiptera, Miridae, Bryocorinae, Bryocorini, Bryocoris

\section{INTRODUCTION}

The genus Bryocoris established by Fallén (1829) is a small group in the tribe Bryocorini of the subfamily Bryocorinae. Nineteen members were described from the Palaearctic Region. All members are known to be associated with ferns (Hu and Zheng, 2000; Yasunaga, 2000). This genus is principally characterized by the following features: body small, almost parallel-sided, clothed with dense pubescence; eyes not contiguous with anterior margin of pronotum; vertex with a transverse carina; pronotum convex in lateral view.

In this paper, only two Korean Bryocoris species- $B$. gracilis Linnavuori and B. montanus Kerzhner are examined. Of these, B. gracilis is reported for the first time, based on a single female specimen collected from Mount Hwangmaesan in Gyeongsangnam-do Province.

\section{MATERIALS AND METHODS}

The terminology used in this study follows Schuh and Slater (1995) and Wheeler (2001). All measurements are in millimeters. All voucher specimens examined in the present study are deposited in the collection of the School of Applied Bioscience, Kyungpook National University, Daegu, Korea.

\section{SYSTEMATIC ACCOUNTS}

Order Hemiptera Linnaeus, 1758

Family Miridae Hahn, 1833

Subfamily Bryocorinae Baerensprung, 1860

*To whom correspondence should be addressed

Tel: 82-53-950-5764, Fax: 82-53-951-5764

E-mail: yjkwon@knu.ac.kr
Tribe Bryocorini Baerensprung, 1860

$1 *$ Genus Bryocoris Fallén, 1829

$2 *$ Bryocoris gracilis Linnavuori, 1962 (Fig. 1A, B)

Bryocoris gracilis Linnavuori, 1962: 68; Schuh, 1995: 477;

Kerzhner and Josifov, 1999: 10; Hu and Zheng, 2000: 249;

Yasunaga, 2000: 94; Lin, 2003: 181.

Diagnosis. Body elongate, almost parallel-sided; dorsal surface densely covered with golden pubescence. Head shiny black, clothed with long hairs; vertex with transverse carina. Antennae black; segment 1 pale yellow at basal 1/3, pubescent with long hairs. Rostrum yellowish brown, apex black, not reaching middle coxae. Pronotum black, anterior part narrow, posterior part broadened, lateral margin almost straight; pronotal collar whitish yellow, with long hairs; pronotal disk punctate, with dense pubescence; scutellum black, pubescent with long hairs, basal area weakly concave. Hemelytra uniformly clothed golden pubescence; clavus black, punctate, with dense pubescence; basal $1 / 2$ of corium yellowish, terminal 1/2 blackish; embolium with $2 / 3$ yellowish, the other $1 / 3$ blackish; cuneus pale whitish yellow, apical inner margin with black band; membrane pale smoky brown. Legs yellowish brown; apex of tarsi darkened. Abdomen totally black.

Dimensions. 우: Body length $3.16 \mathrm{~mm}$, head width $0.54 \mathrm{~mm}$, vertex width $0.29 \mathrm{~mm}$, antennal segment $1-4$ length 0.42 : $0.68: 0.47: 0.37 \mathrm{~mm}$, total rostral length $0.53 \mathrm{~mm}$, pronotal length $0.42 \mathrm{~mm}$, pronotal width $0.97 \mathrm{~mm}$, hind femur: tibia: tarsus length $1.00: 0.95: 0.32 \mathrm{~mm}$ and width across hemelytra $1.16 \mathrm{~mm}$.

Material examined. 1 우, Korea, Gyeongsangnam-do Province, Mt. Hwangmaesan, 7 Aug. 1998, Y.J. Kwon.

Distribution. Korea (new record), Japan, China, Taiwan.

Biology. The biology of this species is poorly known, but this species is Pteridium-inhabitants.

$1 *$ 고사리노린재속, ${ }^{2 *}$ 노랑무늬고사리장님노린재 (신칭) 

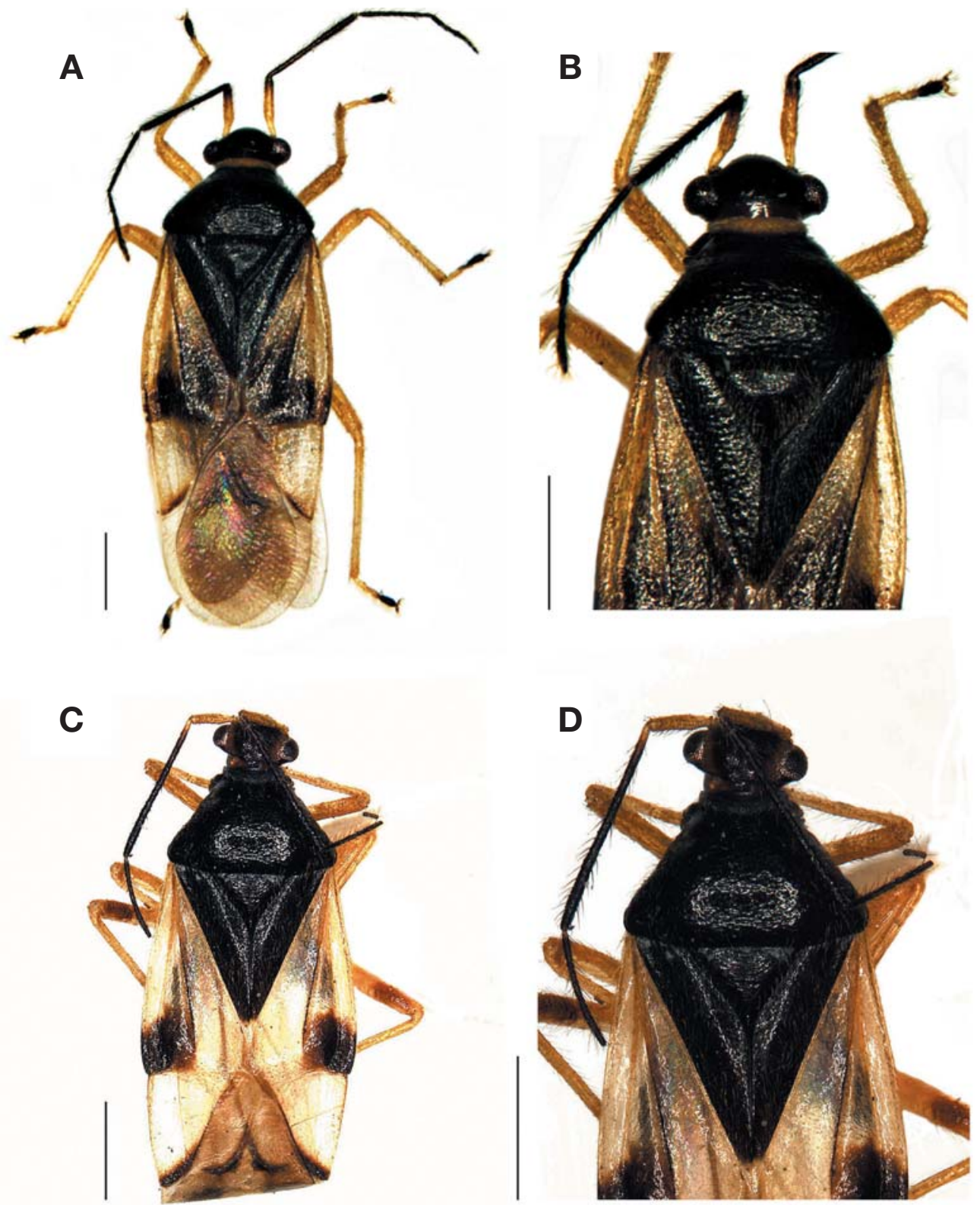

Fig. 1. Bryocoris spp. A, Bryocoris gracilis Linnavuori, habitus; B, ditto, head and thorax; C, Bryocoris montanus Kerzhner, habitus; $D$, ditto, head and thorax. Scale unit: $0.5 \mathrm{~mm}$.

${ }^{1 *}$ Bryocoris montanus Kerzhner, 1972 (Fig. 1C, D)

Bryocoris montanus Kerzhner, 1972: 281; Schuh, 1995: 477;

Kerzhner and Josifov, 1999: 10; Yasunaga, 2000: 94;

Kwon et al., 2001: 88.

Diagnosis. Macropterous form. Dorsal surface densely covered with golden pubescence. Head shiny black. Antennae black; segment 1 brown. Pronotal collar dull; pronotal disk punctate, with dense pubescence; scutellum black. Hemelytra uniformly clothed golden pubescence; clavus black, punctate; corium with large apical black spot.

Material examined. 1 우, Korea, Gangwon-do Province, Mt. Odaesan, 18 Sep. 1982, Y.J. Kwon.

Distribution. Korea, Japan, Russia.

\section{Key to the Korean species of the genus Bryocoris}

1. Antennal segment 1 pale yellow at basal 1/3; pronotal collar dull

\footnotetext{
$1 *$ 참고사리장님노린재
} 
- Antennal segment 1 entirely brown; pronotal collar pale .. B. gracilis

\section{ACKNOWLEDGEMENTS}

The authors are very grateful to Dr. S.L. An (National Science Museum, Daejeon, Korea) for commenting on the manuscript.

\section{REFERENCES}

Fallén, C.F., 1829. Hemiptera Sueciae. Sectio prima (Hemelytrata). Gothorum, Londini. 188pp.

$\mathrm{Hu}$, Q. and L.Y. Zheng, 2000. A revision of Chinese species of Bryocoris Fallen (Hemiptera: Miridae). Acta Zoot. Sin., 25: 241-267.

Kerzhner, I.M., 1972. New and little known Heteroptera from the Far East of the USSR. Trudy Zool. Inst. Akad. Nauk SSSR, 52: 276-295.

Kerzhner, I.M. and M. Josifov, 1999. Catalogue of the Heteroptera of the Palearctic Region, Volume 3. Cimicomorpha II. In: Netherlands Entomological Society (Eds., B. Aukema and C. Rieger). Amsterdam. xiv+577pp.

Kwon, Y.J., S.J. Suh and J.A. Kim, 2001. Hemiptera. Economic
Insects of Korea 18. Ins. Koreana, Suppl. 25: 513.

Lin, C.S., 2003. New Species and New Records of Taiwanese Bryocoris Fallen (Hemiptera; Miridae). Form. Entomol., 23: 179-188.

Linnavuori, R.E., 1962. Contributions to the Miridae fauna of the Far East II. Ann. Ent. Fenn., 28: 68-69.

Reuter, O.M., 1906. Capsidae in prov. Sz'tschwan Chinae a D.G. Potanin et M. Beresowski collectae. Ezheg. Zool. Muz. Imp. Akad. Nauk, 10: 1-81.

Schuh, R.T., 1995. Plant bugs of the world (Insecta: Heteroptera: Miridae). Systematic catalog, distributions, host list and bibliography. The New York Entomological Society. xii, 1329pp.

Schuh, R.T. and J.A. Slater, 1995. True bugs of the world (Hemiptera: Heteroptera). Cornell University Press, Ithaca and London, 336pp.

Wheeler, A.G. Jr., 2001. Biology of the Plant Bugs (Hemiptera: Miridae). Cornell University Press, Ithaca and London, 507pp.

Yasunaga, T., 2000. An annotated list and descriptions of new taxa of the plant bug subfamily Bryocorinae in Japan (Heteroptera: Miridae). Biogeography, 2: 93-102.

Received September 2, 2010 Accepted November 12, 2010 